\title{
The Development of Multimedia and Activities to Promote Products Made by State Enterprise Communities in the Bangmod Project 4.0 Through Community-Based Learning
}

\author{
Kuntida Thamwipat ${ }^{1}$, Pornpapatsorn Princhankol ${ }^{1} \&$ Naphat Deeyen ${ }^{1}$ \\ ${ }^{1}$ Faculty of Industral Education and Technology, King Mongkut's University of Technology Thonburi, Bangkok, \\ Thailand \\ Correspondence: Kuntida Thamwipat, Faculty of Industral Education and Technology, King Mongkut's \\ University of Technology Thonburi, Bangkok, Thailand.
}

Received: November 16, 2018

doi:10.5539/ies.v12n4p49
Accepted: December 20, 2018 Online Published: March 20, 2019

URL: https://doi.org/10.5539/ies.v12n4p49

\begin{abstract}
This research was aimed to explore the demands of the people in the communities in order to develop multimedia and activities to promote products made by state enterprise communities in the Bangmod Project 4.0 through Community-Based Learning among undergraduate students of King Mongkut's University of Technology Thonburi, to examine the perception and the satisfaction of the local people regarding the multimedia and activities, to evaluate the work and to determine the satisfaction of the students towards Community-Based Learning. The tools in this study consisted of 1) the questionnaire on the demands of the local people regarding the multimedia and activities, 2) the multimedia and activities to promote products made by the state enterprise communities in Bangmod Project 4.0 which included offline and online contents as well as special activities, 3) the quality evaluation forms in terms of contents and media presentation, 4) the perception survey form, 5) the satisfaction questionnaire for the local people, 6) the self-evaluation form for students, and 7) the satisfaction questionnaire for students towards the community-based learning. There were two sampling groups as in 1) 22 local people out of 4 state enterprise communities which participated in Bangmod Project 4.0 and they were purposively chosen for this research, 2) 30 undergraduate students who enrolled in the ETM 358 Marketing Communications course which followed the community-based learning approach and these students were purposively chosen out of those who went to the field at least 4 times. The research results showed that the local people in the state enterprise communities expressed a level of demands on the multimedia and activities to promote their products for online and offline media as well as special activities. They wanted to promote 12 products. The quality of the multimedia and activities as evaluated by the experts in contents showed that the quality was at a very good level $(\overline{\mathrm{x}}=4.67$, S.D. $=0.20)$. The quality of the media presentation was at a very good level $(\overline{\mathrm{x}}=4.87$, S.D. $=0.24)$. The perception level of the local people about the multimedia and activities was at a high level $(\overline{\mathrm{x}}=4.41$, S.D. $=0.18)$ and the local people expressed the highest level of satisfaction towards the multimedia and activities $(\overline{\mathrm{x}}=4.80$, S.D. $=0.79)$. The students rated themselves at a very good level $(83.72 \%)$ and their satisfaction towards the community-based learning was at the highest level $(\overline{\mathrm{x}}=4.77$, S.D. $=0.24)$. It can be concluded that the multimedia and activities to promote products made by state enterprise communities in Bangmod Project 4.0 through Community-Based Learning were of good quality and they could be used to promote the products of the local communities.
\end{abstract}

Keywords: multimedia, activities, publicity, state enterprise communities, community-based learning

\section{Background and Significance}

In the past, televisions and radios as well as newspapers were the main sources of information for people in the society. However, in the age of digital and multimedia contents, the production and the creation of digital contents have changed in different directions. Therefore, the social world or social media is so powerful that there are new contents every minute. Since the beginning of the $21^{\text {st }}$ century, digital contents have played a significant role in mass communications. Many people start to use digital channels to create and distribute their contents and they can create their contents freely. If the practice is done in a positive manner, it will be useful for the development of humans, societies and countries in the future (Koedwibunvech, 2016). Therefore, the current era has seen a big popularity among content creators. 
Multimedia is a combination of many kinds of media including material, device and method in order to achieve maximum effectiveness and efficiency in communication. Each media is used in a step-by-step manner in order to present the data in terms of characters, graphics, still images, moving pictures as well as sounds (Malithong, 1997). This multimedia can be used to communicate alongside contents of high quality at the right timing in order to create a special activity and as such the quality of such communication will be at a very good level (Yampinij, 2018). And social media tools are a key resource for professionals looking to implement a campaign effectively across different platforms. Most also provide analytics on performance and engagement, allowing users to tailor future campaigns to increase efficiency (Duffy, 2018).

At present, there are many approaches to learning. Each period tends to be dominated by a certain theory and over the past decades we have seen many interesting theories of learning. To illustrate, constructionism which seems to resonate with the $21^{\text {st }}$ century learning is about the belief that learning takes place when learners create their own bodies of knowledge out of their previous knowledge or acquired knowledge. Therefore, there has been a change in learning and teaching to fit the $21^{\text {st }}$ century classroom in which the teachers have more roles regarding their instruction. Active learning is any approach to instruction in which all students are asked to engage in the learning process. Active learning stands in contrast to "traditional" modes of instruction in which students are passive recipients of knowledge from an expert. Active learning can take many forms and be executed in any discipline. Commonly, students will engage in small or large activities centered around writing, talking, problem solving, or reflecting (Center for Educational Innovation University of Minnesota, 2018). Based on this learning approach, we can see many models such as Cooperative Learning, Collaborative Learning, Project-Based Learning as well as Community-Based Learning. (Ministry of Education, 2018)

Community-Based Learning or CBL is a way of learning in which a problem is used to stimulate learners to learn about a problem in a local community so that students exercise their analytical skills. They need to hypothesize the problems in the local community and think about solution methods and they can learn about their own disciplines through their engagement in the community. $\mathrm{CBL}$ is a result of working process in which people need to use their understanding and problem-solving skills to deal with the problems. Theoretically, CBL is a technique which allows learners to learn by themselves. They will face challenges and they will learn about how to think in different ways such as critical thinking, analytical thinking, synthetic thinking creative thinking and the like. The main features of CBL are that teachers will become facilitators as well as advisors to students and that learners are in the center stage of their own learning along with their small activities and subgroups (Suwannoi, 2018). In this study, the researchers used such learning approach in the ETM 358 Marketing Communications course during the second semester of the academic year 2017 when students participated in the Bangmod Project 4.0 to enhance moral standards by engaging with state enterprise communities for 4 full months and helped local people develop multimedia and activities to promote products made by 4 state enterprise communities located around King Mongkut's University of Technology Thonburi through Community-Based Learning.

In accordance with the mission plan and strategies as well as the follow-up plan to evaluate and increase the quality of King Mongkut's University of Technology Thonburi (KMUTT), there have been activities around the campus area known as "Social Lab" for students to engage in a social community. This is a learning center for local people who integrate learning with students, staff members and alumni to collaborate with the network communities to share and to develop these communities together. There have been problems for students to solve and to apply their knowledge as well as technology with the community enterprise products to promote social enterprise as well as to become aware of resources and environments so that students can make use of their knowledge to meet the demands of Thai society in general (King Mongkut's University of Technology Thonburi, 2018). Social labs are platforms for addressing complex social challenges that have three core characteristics. (Hassan, 2018)

1) They are social. Social labs start by bringing together diverse participants to work in a team that acts collectively. They are ideally drawn from different sectors of society, such as government, civil society, and the business community. The participation of diverse stakeholders beyond consultation, as opposed to teams of experts or technocrats, represents the social nature of social labs.

2) They are experimental. Social labs are not one-off experiences. They're ongoing and sustained efforts. The team doing the work takes an iterative approach to the challenges it wants to address, prototyping interventions and managing a portfolio of promising solutions. This reflects the experimental nature of social labs, as opposed to the project-based nature of many social interventions.

3) They are systemic. The ideas and initiatives developing in social labs, released as prototypes, aspire to be systemic in nature. This means trying to come up with solutions that go beyond dealing with a part of the whole or symptoms and address the root cause of why things are not working in the first place. 
According to the interview with Naksutthi (2018) the Chairperson of the state enterprise community for agricultural tourism in Bangmod Area, agricultural tourism had not gained much attention from people because the publicity was insufficient and there was no support from the governmental sector to develop the agricultural tourism in a sustainable manner. According to the interview with Leewangsee (2018) the Chairperson of the Community Under the Bridge Zone 1, there were many highlight products by the community such as old junk and patented notebooks made out of recycled papers as well as youth drum club. However, many people were not aware of such products. As for Pajongkitjakarn (2018) the Chairperson of the Lang Suan Thonburirom Community, there were many handcraft products such as Chula kites and products made out of coconut shells. However, the lack of publicity meant that the sales were not good enough. According to Thamathanakom (2018) a teacher at Klong Toei Good Will Center School, the main problem of Thai youth dancing club was that although they would like to get jobs during their free time, they could not do it because many people did not know about them. The main problem was due to lack of publicity. Every community participated in the Bangmod Project 4.0 to enhance moral standards among state enterprise communities by KMUTT because they wanted to develop multimedia and activities to promote their products.

Based on the above-mentioned reasons, the researchers with background in learning technology and mass communications at KMUTT decided to do this research to develop multimedia and activities to promote products made by state enterprise communities in the Bangmod Project 4.0 through Community-Based Learning among undergraduate students of KMUTT.

\section{Objective}

1) To explore the demands of the local people in the communities regarding the development of multimedia and activities to promote products made by state enterprise communities in the Bangmod Project 4.0 through community-based learning

2) To develop and to determine the quality of the multimedia and activities to promote products made by state enterprise communities in the Bangmod Project 4.0 through community-based learning

3) To examine the perception and the satisfaction of the local people in the communities towards the multimedia and activities to promote products made by state enterprise communities in the Bangmod Project 4.0 through community-based learning

4) To evaluate the work and to determine the satisfaction of the students towards the development of the multimedia and activities to promote products made by state enterprise communities in the Bangmod Project 4.0 through community-based learning

\section{Research Hypotheses}

1) The demand of the sampling group about the development of the multimedia and activities to promote products made by state enterprise communities in the Bangmod Project 4.0 would be at a high level.

2) The quality of the multimedia and activities to promote products made by state enterprise communities in the Bangmod Project 4.0 would be at a good level.

3) The local people would express a high level of satisfaction towards the multimedia and activities to promote products made by state enterprise communities in the Bangmod Project 4.0.

4) The students would express a high level of satisfaction towards community-based learning and their work would be at a good level.

\section{Expected Outcomes}

1) There would be multimedia and activities to promote products made by state enterprise communities in the Bangmod Project 4.0 which could be distributed to people who are interested to expand its circulation.

2) The local people would participate in the development of the multimedia and activities to promote products made by state enterprise communities.

3) The knowledge from this research study could be used as a way to promote other kinds of active learning for students in the future.

\section{Research Scope}

The multimedia and activities to promote products made by state enterprise communities in the Bangmod Project 4.0 included both offline and online media. Offline media included calendars, vinyl boards, rollups and leaflets with QR code technology to promote products made by the state enterprise communities in the Bangmod Project 4.0. Online media included Facebook fanpage for the Bangmod Project 4.0 and Youtube video clips about 12 
national values. The special activities included fieldwork to make relationship with the local people and the discussion meeting.

\subsection{Populations}

There were 2 kinds of population in this study.

1) The 40 entrepreneurs from 4 state enterprise communities included the Community Under the Bridge Zone 1, the Lang Suan Thonburirom Community, the Moo 3 Bangmod Community, and the Klong Toei Community.

2) There were 93 third-year undergraduate students from the Department of Educational Communications and Technology from Faculty of Industrial Education and Technology, KMUTT who enrolled in the ETM 358 Marketing Communications course in the second semester of the academic year 2017.

\subsection{Sampling Groups}

There were 2 sampling groups as follows:

1) There were 22 entrepreneurs from these 4 state enterprise communities who had worked for at least 2 years and were willing to participate in the questionnaire survey. These people were chosen using purposive sampling method.

2) There were 30 students who were chosen using purposive sampling method out of those who had been to the communities for at least 4 times and were willing to participate in the research questionnaire survey.

\subsection{Expert Panel}

The experts were those with knowledge and expertise in the evaluation of the quality of the multimedia and activities to promote products made by state enterprise communities in the Bangmod Project 4.0. They were chosen using specified sampling method out of those who were qualified and willing to be in the expert panel for this research. There were 3 experts in contents, 3 experts in media presentation, and 3 experts who were experienced with measuring and evaluating the IOC value of the interview schedule and the questionnaires.

\section{Research Tools}

This research contained the following research tools

1) The questionnaire on the demands of the local people in the communities regarding the development of multimedia and activities to promote products made by state enterprise communities in the Bangmod Project 4.0

2) The multimedia and activities to promote products made by state enterprise communities in the Bangmod Project 4.0

3) The quality evaluation forms in terms of contents and media presentation of the multimedia and activities to promote products made by state enterprise communities in the Bangmod Project 4.0

4) The perception survey form for the local people about the development of the multimedia and activities to promote products made by state enterprise communities in the Bangmod Project 4.0

5) The satisfaction questionnaire for the local people about the development of the multimedia and activities to promote products made by state enterprise communities in the Bangmod Project 4.0

6) The self-evaluation form for students who enrolled in the ETM 358 Marketing Communications course about Community-Based Learning

7) The satisfaction questionnaire for students towards the Community-Based Learning

\section{Data Analysis}

The research data were from interviews and questionnaires. The data were analyzing using the following statistical techniques: mean score and standard deviation.

\section{Research Results}

1) Results from the interview about the demands of the local people regarding the multimedia and activities to promote products made by state enterprise communities in the Bangmod Project 4.0:

According to the interview with Leewangsee (2018), the Chairperson of the Community Under the Bridge Zone 1, the demand for Facebook fan page, posters, leaflets and activities to promote products made by the local people was at a high level. There were 3 kinds of products in the community and these were old junk, patented notebooks made out of recycled papers as well as youth drums. 
According to the interview with Pajongkitjakarn (2018), the Chairperson of the Lang Suan Thonburirom Community, there were 2 major handcraft products and these were Chula kites and products made out of coconut shells. Their demand for publicity, multimedia and activities to promote their products was at a high level. They would prefer rollups, Facebook fan page, Youtube video clips and discussions in the community.

According to the interview with Naksutthi (2018), the Chairperson of the state enterprise community for agricultural tourism in Bangmod Area, there were 6 types of agricultural products and these were Bangmod orange for preservation and trade, Mafeung orchard, Madue Farang orchard, food and drink, soaps, shampoos, washing-up liquid made of herbs, and fish. Therefore, the community's demand for multimedia and activities to promote their products was at a high level. They would prefer rollups, vinyl, Facebook fan page, Youtube video clips and discussions in the community.

According to Thamathanakom (2018), a teacher at Klong Toei Good Will Center School, the demand for multimedia and activities to promote its Thai youth dancing club was at a high level. The youth could work part-time and they would prefer name cards, posters, rollups, Facebook fan page, and seminars about Thai dancing with other youths and they could perform one show.

It can be concluded that there was a high level of demand in these communities for the multimedia and activities to promote their products. This confirmed the research hypothesis regarding the demand for online or offline media and special activities. There were 12 kinds of products and the researchers would use this information to develop multimedia and activities in the next phase.

2) Results from the development of multimedia and activities to promote products made by state enterprise communities in the Bangmod Project 4.0:

The Bangmod Project 4.0 was aimed to support virtues and guidance to local communities during the second semester of the academic year 2017. During the whole semester, there were 5 phases for the development of multimedia and activities based on the ADDIE Model (Office of the National Primary Education, 1997) as shown in the table below:

\begin{tabular}{|l|l|l|}
\hline Phase & Month & Details \\
\hline 1. Analysis & January & $\begin{array}{l}\text { We made a plan and interviewed the 4 local communities about } \\
\text { their demands for 12 types of products and took photos with a } \\
\text { plan to make a desk calendar. }\end{array}$ \\
\hline 2. Design & February & $\begin{array}{l}\text { We made a MV about 12 national values to promote virtues for } \\
\text { all 4 local communities and we uploaded it to Youtube. We } \\
\text { designed activities to meet the demands of the communities. }\end{array}$ \\
\hline 3. Development & March & $\begin{array}{l}\text { We went to the 4 local communities and took still photos and } \\
\text { created video clips for 12 products and we created a calendar. } \\
\text { We used QR code technology to help promote the products. } \\
\text { We produced rollups, posters and leaflets for publicity. }\end{array}$ \\
\hline 5. Evaluation & March & $\begin{array}{l}\text { We gave the multimedia to the communities so that they could } \\
\text { sell and use the money as fund to support their local } \\
\text { communities. We taught the communities to use social } \\
\text { networks in order to sell products on their Facebook fan page. }\end{array}$ \\
\hline
\end{tabular}

The procedure underwent 9 steps as described in the ETM 358 Marketing Communications course as follows:

A) We created a simulated company: ECT Agency-structural democracy.

- All students in the whole class assigned their work based on their willingness and ability.

- The students voted for the chairperson of this project as well as the committee members.

B) We learned from the lessons created by previous generations about their work in underprivileged communities.

- The lesson learned from the previous generation students helped the current students to find ways to improve their work. 
C) The problems for this project had to come from the discussions between the university and the local people.

- The information and viewpoints had to be shared among the people. For students, their supervisors would act as the middlepersons to create as well as to maintain the connections inside and outside the university (such as relevant organizations, funding bodies and sponsors).

D) According to the principle of Community-Based Learning, there are 4 main elements known as "CLTE". In order to do the learning management, there are 4 areas to be taken into account (Chatsuriyawong, 2014):
a) Community
b) Learning
c) Technology
d) Evaluation

There are 4 elements in the learning paradigm as follows:

a) Principle: The learning in the community must consider 4 areas of "CLTE" and learners have to gain first-hand practice and to solve problems through different ways of learning in order to get a creative solution.

b) Objective: The objective is to promote the ability to think critically and to use creativity in their problem-solving among primary school students.

c) The management: The management must follow the PSRA learning approach: (1) Preparing: P, (2) Strategies: S, (3) Reflection: R and (4) Assessing: A. The assessment comes from the community and the learner.

d) Conditions: To use the learning paradigm successfully, there must be these conditions:

- The community supports, encourages and participates in each step.

- The learners go to the local community themselves, collect the data, use their thinking skills and solve the problems according to the real situations.

- There must be flexibility with time management to fit the schedule outside the classroom.

E) We measured, evaluated and presented the data in the project report based on the principle of "Plan-Do-Check-Act" by Deming (2018) Shewhart Cycle.

F) Students submitted their project result to national competitions to practice their presentation skills. On this occasion, we submitted it to the Democratic Innovation Event held by the Secretariat of the House of Representatives.

G) Supervisors and chairperson student wrote a research report and presented it in a national or international conference to share the lessons learned every year.

H) We worked under the principle of Win-Win situation: Students and the local communities both win.

I) The main output from the research: the mass media, the main media and the social media, paid attention to the data and information which is beneficial to many educational institutions every year.

Images which show the development of multimedia and activities to promote products made by state enterprise communities in the Bangmod Project 4.0 through community-based learning: 


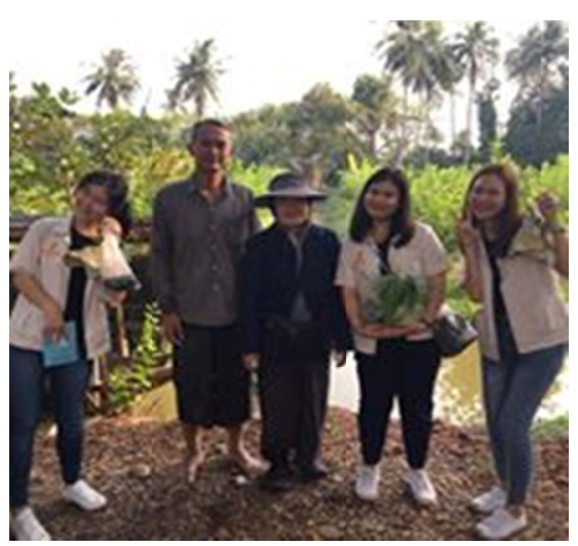

\begin{tabular}{|l|l|}
\hline Phase 1. Analysis & January \\
\hline
\end{tabular}

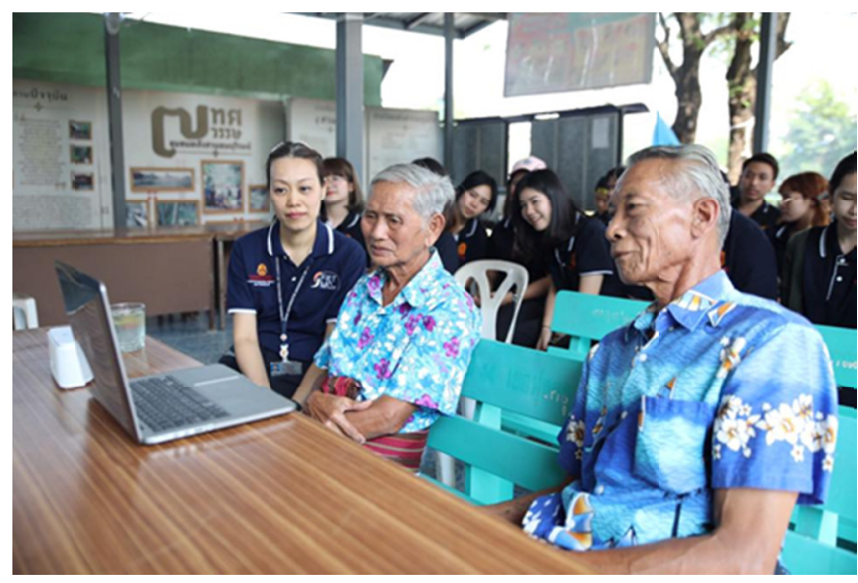

We made a plan and interviewed the 4 local communities about their demands for 12 types of products and took photos with a plan to make a desk calendar.
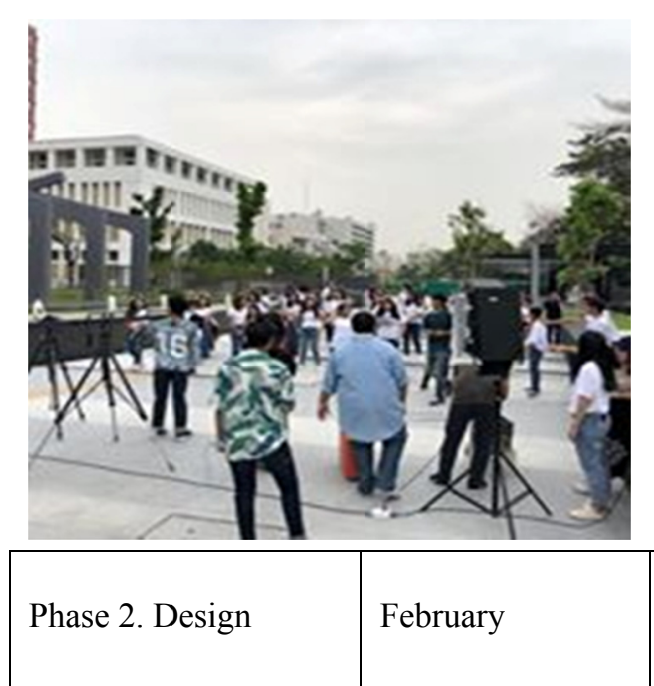

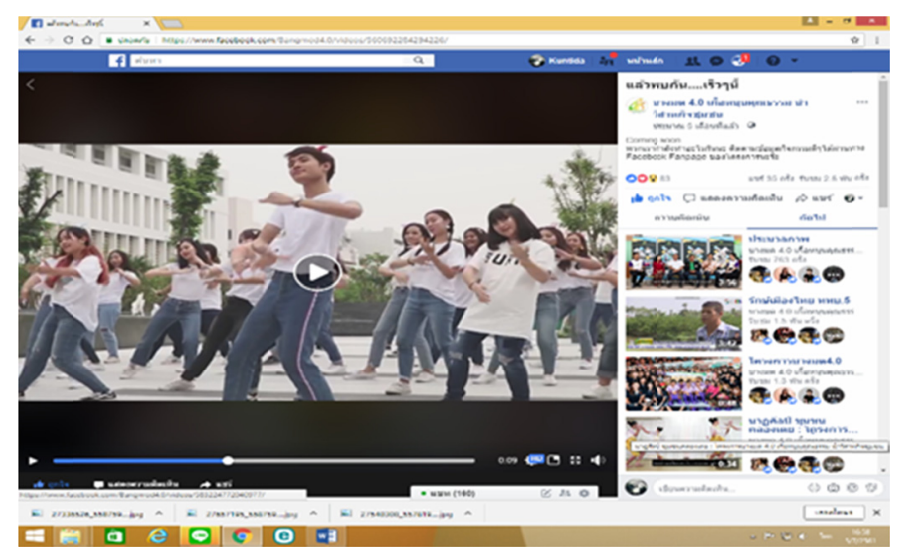

We made a MV about 12 national values to promote virtues for all 4 local communities and we uploaded it to Youtube. We designed activities to meet the demands of the communities.
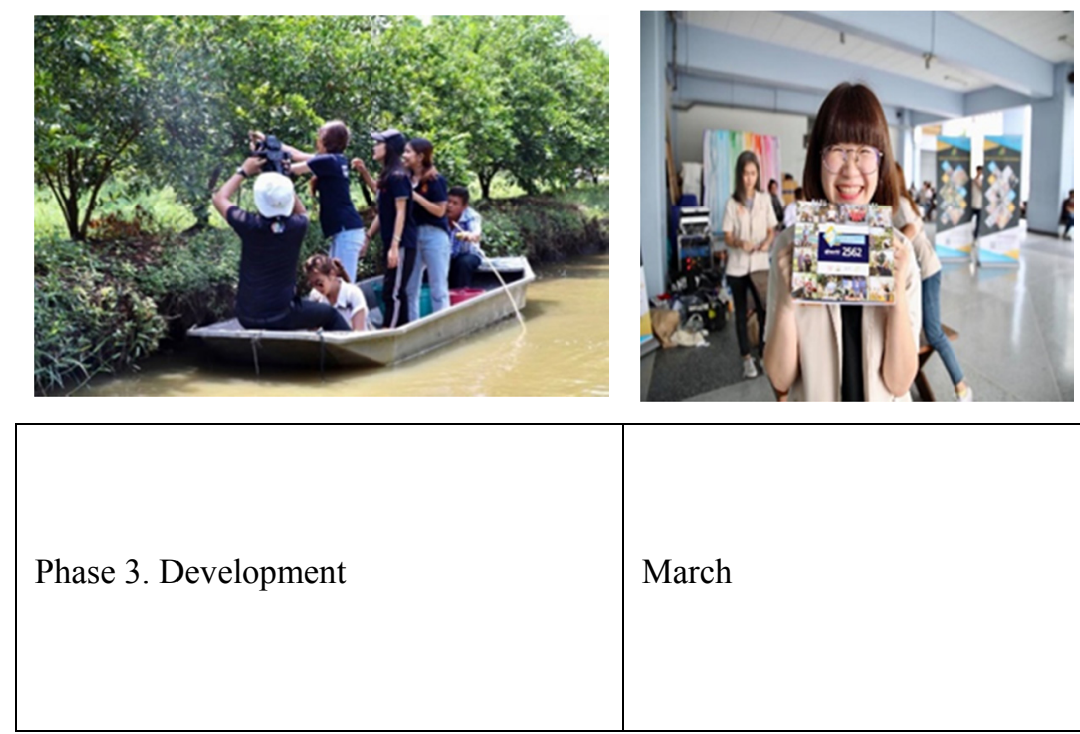

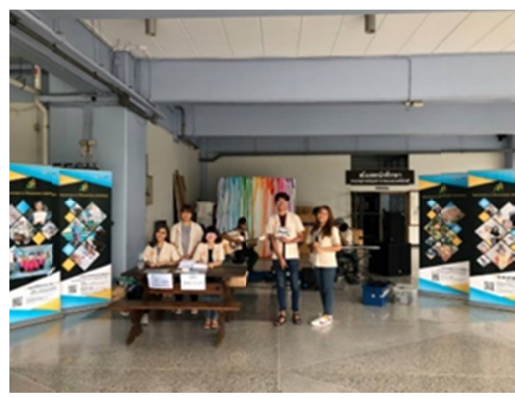

We went to the 4 local communities and took still photos and created video clips for 12 products and we created a calendar. We used $\mathrm{QR}$ code technology to help promote the products. We produced rollups, posters and leaflets for publicity. 

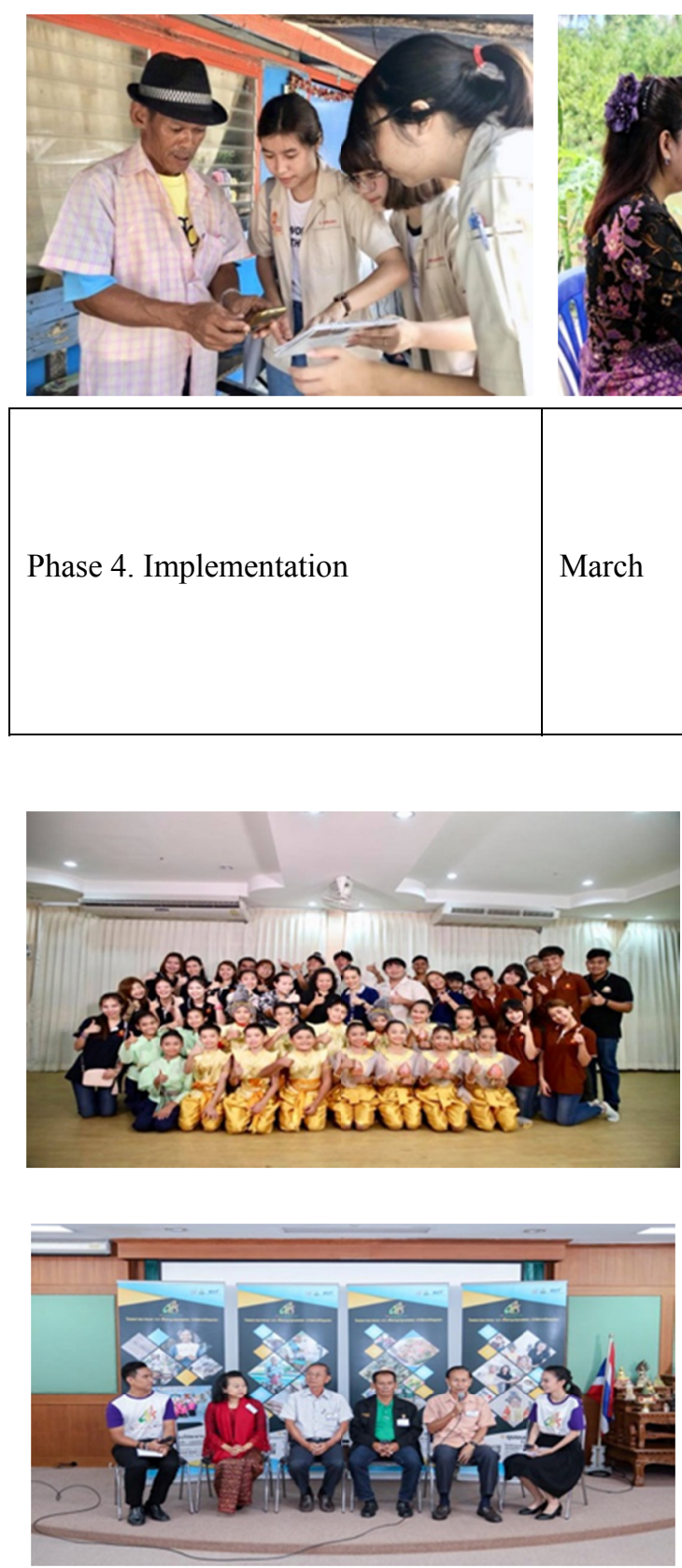

\begin{tabular}{|l|l|l|}
\hline Phase 5. Evaluation & April & $\begin{array}{l}\text { We organized activities and seminars as well as discussions } \\
\text { to promote the local communities and their products. Then, } \\
\text { we evaluated the results. }\end{array}$ \\
\hline
\end{tabular}
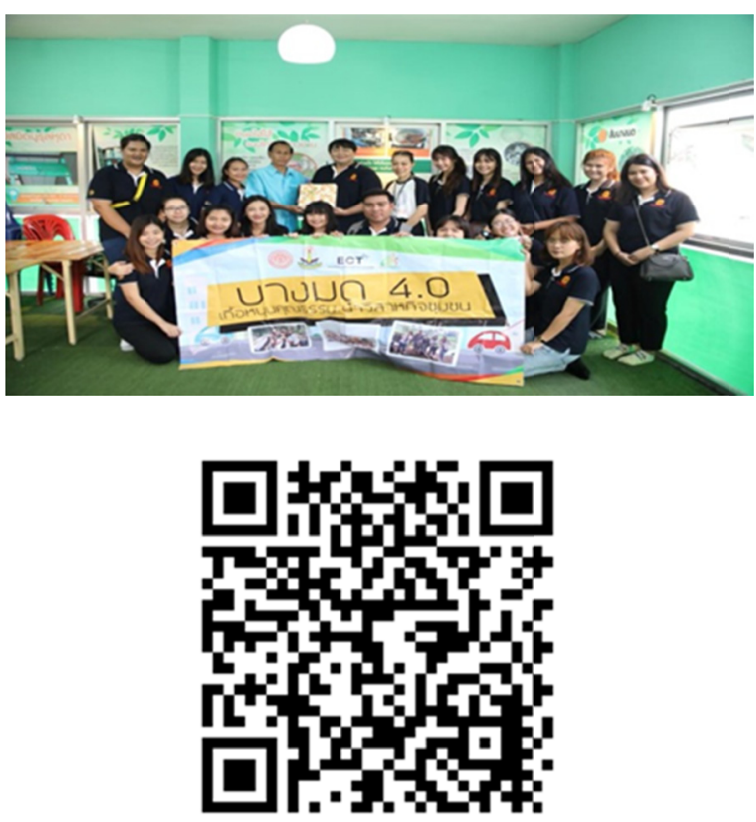

We gave the multimedia to the communities so that they could sell and use the money as fund to support their local communities. We taught the communities to use social networks in order to sell products on their Facebook fan page.

3) Results from the evaluation of the quality of the multimedia and activities to promote products made by state enterprise communities in the Bangmod Project 4.0.

Table 1 . The quality of the multimedia and activities as evaluated by the expert panels

\begin{tabular}{lccl}
\hline Item & $\overline{\boldsymbol{x}}$ & S.D. & Meaning \\
\hline Quality of the contents & 4.67 & 0.20 & Very good \\
Quality of the media presentation & 4.87 & 0.24 & Very good \\
\hline
\end{tabular}

The quality of the contents of the multimedia and activities to promote products made by state enterprise 
communities in the Bangmod Project 4.0 as evaluated by the experts was at a very good level $(\bar{x}=4.67$, S.D. $=0.20)$. The quality of the media presentation was also at a very good level $(\bar{x}=4.87$, S.D. $=0.24)$. The results confirmed the research hypothesis.

4) Results about the perception and the satisfaction of the communities towards the multimedia and activities to promote products made by state enterprise communities in the Bangmod Project 4.0.

Table 2. The results about the perception and the satisfaction of the communities towards the multimedia and activities

\begin{tabular}{lccc}
\hline Item & $\overline{\boldsymbol{x}}$ & S.D. & Meaning \\
\hline Perception level & 4.41 & 0.18 & High \\
Satisfaction level & 4.80 & 0.79 & The Highest \\
\hline
\end{tabular}

The perception level of the local people about the multimedia and activities was at a high level $(\overline{\mathrm{x}}=4.41$, S.D. $=$ $0.18)$ and the local people expressed the highest level of satisfaction towards the multimedia and activities $(\overline{\mathrm{x}}=$ 4.80, S.D. $=0.79$ ). The results confirmed the research hypothesis.

Table 3. The self-evaluation made by students about the community-based learning

\begin{tabular}{lccc}
\hline Item & Before & After & Meaning \\
\hline Self-evaluation results (Active level) & $37.73 \%$ & $83.72 \%$ & Very Good \\
\hline
\end{tabular}

Table 4. The satisfaction of the students towards the community-based learning

\begin{tabular}{lccc}
\hline Item & $\bar{x}$ & S.D. & Meaning \\
\hline Satisfaction level & 4.77 & 0.24 & The Highest \\
\hline
\end{tabular}

The results from the self-evaluation by the students show that before their study their active level was $37.73 \%$ but after their study their active level was $83.72 \%$ or at a very good level. The satisfaction level of the students towards the community-based learning was at the highest level $(\overline{\mathrm{x}}=4.77$, S.D. $=0.24)$. The results confirmed the research hypothesis.

\section{Research Discussions}

This research into the development of the multimedia and activities to promote products made by state enterprise communities in the Bangmod Project 4.0 through community-based learning followed the principles of community-based learning (Global Fund Office, 1995) which are important to the development of education in Thailand which states: Schools or educational institutes are a large manufacturing place. Educational institutes are a mechanism to develop humans and the nation to keep up to date with the advances in the world so that humans can use their knowledge to organize themselves. On the contrary, educational plans tend to separate humans from the communities, societies, cultures and souls of the locality until they forget their roots, their ways of life and their individuality. In this research, we adopted ADDIE Model (Office of the National Primary Education, 1997) which consists of Analysis, Design, Development, Implementation and Evaluation. Each step was supervised by experts in order to check the quality in terms of contents, media and activities, as well as measurement and evaluation. The results from the interviews with the local people regarding the demands and their requirements about the multimedia and activities to promote products made by state enterprise communities in the Bangmod Project 4.0 through community-based learning showed that the local communities had good-quality products but lacked publicity. Therefore, their products were unknown (Naksutthi, 2018). They would like to have online media, offline media and special activities as well as the publicity of their 12 products. The researchers, therefore, developed multimedia and activities based on these demands.

The quality of the contents of the multimedia and activities to promote products made by state enterprise communities in the Bangmod Project 4.0 was at a very good level $(\bar{x}=4.67, \mathrm{~S} . \mathrm{D} .=0.20)$. The quality of the media presentation was also at a very good level $(\bar{x}=4.87$, S.D. $=0.24)$. The results confirmed the research hypothesis and complied with the research entitled "Developing a Lesson Based on the 'Service-Learning' Principle through the Project to Create a Community Calendar to Promote 12 Values" (Thamwipat, Princhankol and Kaewket, 2017). Because the Quality of the contents as examined by the expert revealed that the quality was at a good level $(\bar{x}=$ 
4.04, S.D. $=0.39)$ and the quality of the media presentation was at a very good level $(\bar{x}=4.57$, S.D. $=0.42)$ whereas the quality of the activity design was at a good level ( $\bar{x}=4.05$, S.D. $=0.10)$.

The perception level of the local people about the multimedia and activities was at a high level $(\overline{\mathrm{x}}=4.41$, S.D. $=$ $0.18)$ and the local people expressed the highest level of satisfaction towards the multimedia and activities $(\overline{\mathrm{x}}=$ 4.80, S.D. $=0.79)$. The results confirmed the research hypothesis and complied with the ideas of Chuangchot et al. (1972) in that the perception is a kind of exposure with meaning in order to evaluate or interpret the sensory data. In this case, the perception of the local community was about the multimedia and activities to meet the demands of the local people. Therefore, their perception was at the highest level. This research was similar to the research study done by Patsarathorn and Thamwipat (2016) entitled "The Development of Historical Learning Resources in the Community in the Topic of 7 Decades Lung Suan Thonburirom Community" which shows that the people in Lung Suan Thonburirom Community expressed their satisfaction at the highest level $(\bar{x}=4.58$, S.D $=0.55)$.

The results from the self-evaluation by the students show that before their study their active level was $37.73 \%$, but after their study their active level was $83.72 \%$ or at a very good level. The satisfaction level of the students towards the community-based learning was at the highest level $(\overline{\mathrm{x}}=4.77$, S.D. $=0.24)$. The results confirmed the research hypothesis and complied with the research by Chatsuriyawong (2014) who studied the paradigm of the community-based learning to promote critical thinking and creative problem solving for primary students. The results showed that after the learning activities, students increased their critical thinking and creative problem solving with statistical significance at the. 05 level. Their satisfaction towards the paradigm of the community-based learning was at the highest level. This was because the community-based learning could increase the critical thinking skill and the creative problem solving skill from the real problems in the communities. Moreover, there was support from the educational institute and the private sector. The learners expressed the highest level and their self-evaluation showed that their active level was at a very good level after the 9 procedures in the ETM 358 Marketing Communications as described above. Complied with the research by Meehta (2011) who studied Corporate Social Responsibility (CSR) and Universities:Towards an Integrative Approach, the results showed that CSR can be implemented within an academic framework. The project of students of this university to voice the histories of the nation is an immediate example of the way in which universities can facilitate community involvement by empowering students to discover individual histories and, as a result, help to re-define nation and society.

\section{Suggestions}

\subsection{Suggestions from the Research Results}

1) The multimedia and activities to promote products made by state enterprise communities in the Bangmod Project 4.0 through community-based learning have allowed people to access the data both online and offline so that more people could gain access to the local products.

2) The community-based learning is an active learning approach and the learners expressed the highest level of satisfaction. Therefore, other active learning approaches should be encouraged such as service learning, project-based learning, and outcome-based learning.

\subsection{Suggestions for Further Research}

1) There should be a study into the analysis of learning factors of the community-based learning through social lab around the campus of King Mongkut's University of Technology Thonburi.

2) There should be a study into the development of online media to promote products made by state enterprise communities to a global market alongside the community-based learning approach.

\section{Acknowledgements}

The researchers would like to express their gratitude towards Faculty of Industrial Education and Technology, King Mongkut's University of Technology Thonburi and other private organizations for their funding in the research and development of the multimedia and activities in this research.

\section{References}

Center for Educational Innovation University of Minnesota. (2018). Active Learning. Retrieved from https://cei.umn.edu/

Chatsuriyawong, S. (2014). The Paradigm of the Community-Based learning to Promote Critical Thinking and Creative Problem Solving for Primary Students (Doctoral Thesis in Curriculum and Instruction, Silpakorn University, Nakhornpathom). 
Chuangchot, C. et al. (1972). Learning Psychology. Sasana Printing House, Bangkok.

Deming, E. W. (2018). Plan-Do-Check-Act (PDCA). Retrieved from https://www.mindtools.com/pages/article/ newPPM_89.htm

Duffy, G. (2018). 6 Social Tools for PR and Communications Professionals. Retrieved from https://www.newswhip.com/2015/10/6-social-tools-for-pr-and-communications-professionals/\#3TwFd4C0j APUKu6b.99

Global Fund Office. (1995). List of Communities Organized according to Bangkok Regulations. Bangkok.

Hassan, Z. (2018). The Social Labs Revolution: A New Approach to Solving our Most Complex Challenges. Retrieved from https://ssir.org/articles/entry/the_social_labs_revolution_a_new_approach_to_solving_our_ most_complex_chall

King Mongkut's University of Technology Thonburi, KMUTT Social Report. (2018). Retrieved from http://www2.kmutt.ac.th/thai/abt_history/info_report/KMUTT-Social-Report-2556-2557.pdf

Koedwibunvech, C. (2016). New Digital Media is Future. National Institute of Development Administration Press, Bangkok.

Leewangsee, C. (2018). Chairperson of the community under the bridge zone 1. Interview, 21 January 2018.

Malithong, K. (1997). Educational Innovation and Technology. Chulalongkorn University Press, Bangkok.

Mehta. S. R. (2011). Corporate Social Responsibility (CSR) and Universities:Towards an Integrative Approach. International Journal of Social Sciences and Humanity, 1(4), 300-304. https://doi.org/10.7763/IJSSH.2011.V1.55

Ministry of Education, Learning in the 21st Century. (2018) Retrieved from http://www.moe.go.th/moe/th/news/detail.php?NewsID=38880\&Key=news_research

Naksutthi, S. (2018). Chairperson of the state enterprise community for agricultural tourism in Bangmod Area. Interview, 15 January 2018.

Office of the National Primary Education. (1997). Real Assessment of the Students. Kurusapa Printing House, Bangkok.

Pajongkitjakarn, S. (2018). Chairperson of the Lang Suan Thonburirom community. Interview, 19 January 2018.

Patsarathorn, A., \& Thamwipat, K. (2016). The Development of Historical Learning Resources in the Community in the Topic of 7 Decades Lung Suan Thonburirom Community. The 5th International Conference on Learning Innovation in Science and Technology (ICLIST 2016), January 27-29, 2016, Pattaya.

Suwannoi, P. (2018). Community-Based Learning. Retrieved from https://ph.kku.ac.th/thai/images/file/km/pblhe-58-1.pdf

Thamathanakom, N. (2018). A teacher at Klong Toei Good Will Center. Interview, 19 January 2018.

Thamwipat, K. et al. (2017). Developing a Lesson Based on the 'Service-Learning' Principle through the Project to Create a Community Calendar to Promote 12 Values. 3rd International Conference on Education and Distance Learning 2017. Galle Face Hotel,Colombo, Srilanka.

Yampinij, S. (2018). Supervisor and Director Educational Communications and Technology. Interview, 2 February, 2018.

\section{Copyrights}

Copyright for this article is retained by the author(s), with first publication rights granted to the journal.

This is an open-access article distributed under the terms and conditions of the Creative Commons Attribution license (http://creativecommons.org/licenses/by/4.0/). 